\title{
EMPIRICAL ANALYSIS OF EXPORTS OF ORGANIC AGRICULTURAL FOOD PRODUCTS OF UKRAINE
}

\author{
Svitlana Tkalenko', Tetyana Melnyk ${ }^{2}$, Liudmyla Kudyrko³
}

\begin{abstract}
The main goal of the study is to identify endogenous and exogenous factors that determine the scale and dynamics of Ukraine's exports of organic agricultural food products (OAP). The formulated goal caused assessment of a number of potential factors influencing the development of the export potential of the Ukrainian agro-industrial complex in terms of production and sales of organic agricultural products on foreign markets. The authors conducted economic and mathematical modeling based on the software product E-Views. The observation interval covers 2008-2019. Multifactorial regression model has been constructed and tested for heteroscedasticity, as well as causal relationships have been identified between the main indicators of supply and demand and the exports volumes of related organic products. This makes it possible for further forecast on Ukraine's exports in the short and medium term. Methodology. The study has been based on statistics from international and Ukrainian institutions specializing in organic farming and trade, including FiBL (Research Institute of Organic Agriculture), the Federation of Organic Movement of Ukraine. Databases of the State Statistics Service of Ukraine, UNCTAD for the period 2008-2019 were also involved, which made it possible to conduct a full cycle of research procedures in order to identify the most significant factors influencing Ukraine's export activity within related segment of the global market. The results of the conducted modeling show the following: achievement and increase of Ukraine's relative advantage in international trade of organic agro-food products for the outlined years; the existence of strong connection between the volume of exports of organic agro-food products and the level of comparative country's advantages in international trade; identifying a significant impact on exports of endogenous factors, namely the level of wholesale and retail sales on the domestic market of Ukraine as a factor that creates additional demand from the population and business of Ukraine (B2B and B2C markets) for organic products and enhances the attention of agricultural manufacturers to activities that combine the criteria of high profitability and public demand. Another endogenous factor is the volume of areas allocated for organic farming has shown insignificant impact, however, it allows to create resource conditions for increasing production and export activity of national business in a particular sphere on various directions, from meat and dairy products to production of organic fruit, vegetables, etc. Practical implications. Conceptual provisions, conclusions formulated by the authors based on the conducted econometric modeling, allow to optimize the measures of regulatory policy in terms of institutional support of conditions and factors contributing to promising activities of the national agro-industrial complex. This will ensure the implementation of the national strategy on sustainable development with its emphasis achieving environmental criteria of production and consumption, reduce the level of import dependence upon a number of strategically important food groups and, at the same time, increase economic efficiency of Ukrainian agricultural business. Value/originality. Prospects for further research in this area may assess the potential of international production and marketing cooperation between Ukrainian agricultural companies and non-resident companies in terms of limiting the latter's access to the land market in Ukraine while finding flexible mechanisms to stimulate joint production and sale of organic agricultural products on international markets according to quality and safety standards.
\end{abstract}

Key words: exports, comparative trade advantages, organic production, food security, import dependence, standardization, neo-protectionism, COVID-19.

JEL Classifications: F14, F17, F52

\footnotetext{
Corresponding author:

${ }^{1}$ Kyiv National Economic University named after Vadym Hetman, Ukraine.

E-mail: sv.tkalenko@gmail.com

ORCID: https://orcid.org/0000-0003-0385-846X

ResearcherID: https://publons.com/researcher/1924024/svitlana-tkalenko/

${ }^{2}$ Kyiv National University of Trade and Economics, Ukraine.

E-mail: t.melnyk@knute.edu.ua

ORCID: http://orcid.org/0000-0002-3839-6018

ResearcherID: https://publons.com/researcher/1673478/tetiana-melnyk/

${ }^{3}$ Kyiv National University of Trade and Economics, Ukraine.

E-mail:1.kudyrko@knute.edu.ua

ORCID: http://orcid.org/0000-0002-9089-7223

ResearcherID: https://publons.com/researcher/1688352/liudmyla-kudyrko/
} 


\section{Introduction}

The relevance of the issue under study, which is exports of organic agricultural food products in modern conditions, has several aspects. Firstly, currently there is a strong trend within the global market, especially among high-income importing countries, regarding the need to pay more attention to food safety and quality issues that are the object of international trade (Tsvitko, 2018). At the same time, latent neo-protectionist tools are increasingly being used to protect national farmers in conditions of global development crises caused by foreign competition through sophisticated and effective system of national standardization. Secondly, the global demand for quality organic agricultural food products leads to intensification of countries-manufacturers, aggravation of competition between them and the search for effective mechanisms to strengthen their position within highly profitable segments of the global agro-food market. Thirdly, taking into account the fact that the conditions for achieving competitive advantage in this promising and dynamically growing market for each exporting country vary, and along with it the following question arises logically: what forms and strengthens the ability to increase export expansion with organic food from Ukraine, being the country which is actively declaring about its ambitions and claims to create, and it has already created a significant competition for other participants? Thus, in 2019, Ukraine took 2nd place among importers of organic agro-food products to the EU countries, which are one of the world's largest importers of these products, being second only to suppliers from China (Willer et al., 2020). The international prospects of Ukrainian agro-industrial sector look even more convincing if it becomes the object of more active interest from foreign investors (Makhnovets, 2020). Currently, bearing in mind the international comparisons, the investment potential looks huge (Nagachevska et al., 2021).

\section{Literature review}

Theoretical research on international production and marketing of organic food has intensified since the early 2000s, mainly in the EU and the US, primarily in several directions: marketing aspects, crosssectoral interaction of manufacturers, processors and distributors, institutional regulators. Thus, the peculiarities of imports of organic products to the US market have been investigated in terms of domestic and international market dynamics, import assessment as the way to resolve the imbalance between domestic supply of organic food and demand, having determined the role of certification when regulating import procurement (Oberholtzer et al., 2013). New aspects on standardization of organic products have been also considered from the standpoint of meeting consumer demand; however, raising the issue of adjusting the volume of exports and imports (Schäufele and Hamm, 2017). New challenges as for economic problems of the relationship between the sectors of production and processing of organic products, retail trade are becoming the focus of scientific research (Greene et al., 2009). The investigations confirm that the marketing characteristics and properties of organic products have indisputable impact onto the competitive advantages of producers (Mykhaylenko, 2017), their market status and economic efficiency (Dudar, 2019). The discovery of connection between ecological values and production, sale and consumption of organic products has become an urgent scientific problem (Muñoz-Sanchez et al., 2021). Institutional and organizational instruments that influence both domestic and international trade in organic food cannot be considered without overcoming information uncertainty for consumers through food quality labeling, including protected geographical indications (Aitken et al., 2020), which gives overall understanding of food safety and guarantees their protection from unscrupulous manufacturers. Greater demand for transparency over organization of production itself is generated by research on the development of new alternative network formats of production and marketing (Jaouen et al., 2020). More and more actively, the export of organic food onto international markets is seen as the way to modernize national systems of agricultural production (Varia et al., 2021) and its efficiency increase (Ganush et al., 2021). The results of econometric analysis of the factors for development of organic production and trade become the basis for substantiation of proposals for state regulation (Bazaluk et al., 2020).

There is no way to ignore the new aspect of sectoral studies of global and national development of agricultural sector, which may compete with the issue of food organics. They are about finding answers to the pressing questions: what exactly is going to be the impact of COVID-19 on income, nutrition and, ultimately, food security? Preliminary forecasts have been quite disappointing: by 2020 the number of people staying in conditions that do not meet acceptable level of food security reached 761 million people, or 19.8 percent of the total population (that is 76 low- and middle-income countries); it is projected that the shock to GDP from COVID-19 will rise the number of people whose living conditions are far from food security criteria, i.e., it has grown by 83.5 million in 2020 up to 844.5 million and increased this share to 22 percent (Baquedano et al., 2020).

A retrospective review of scientific research indicates that the issue of international trade in agricultural food products is multifaceted indeed, that needs further research, achieving the balance of economic, environmental, security and institutional levers of control and promotion. 


\section{Methodology}

The conducted research deals with the usage of databases from international and Ukrainian specialized institutions, organizations and the National statistics service in Ukraine for the period of 2009-2019. Authors formulated preliminary assumption that volumes of OAP production and export depend on a number of factors, featuring endogenous (domestic, national) and exogenous (international) origin. Some of them relate to direct and indirect indicators of market supply, in particular world exports of OAP (in mln EUR); the number of operators and exporters of OAP on the world market (units), the area for OAP production in Ukraine (hectares), the number of certified enterprisesmanufacturers of OAP in Ukraine (units), the index of relative advantage of Ukraine's OAP exports; others market demand, in particular wholesale and retail sales of OAP in Ukraine (in mln EUR), GDP per capita in Ukraine (EUR). In addition, authors considered it expedient to check the probability of the influence of monetary levers of the institutional environment through the weighted average Hryvnia exchange rate for 100 EUR.

All indicators, except for the Index of relative advantage of Ukraine's OAP exports are obtained from public sources. (RXAij) is a calculated value, and has been determined by the authors through the following formula: $R X A_{i j}=\frac{E_{i j}}{E_{s j}} \sqrt{ } \frac{E_{i w}}{E_{s w}}$,

where $E_{i j}$ is an export of $i$ of country product $j$; $E_{s j}$ is the total exports of country $j$; Eiw is the world exports of i products; $E_{s w}$ is the global exports.

The most relevant and significant factors influencing the export of OAP on the basis of the conducted analysis as for dependence of qualitative variables on many factors based on the normal distribution (Prob.) with the help of E-Views showed the following:
- index of relative export advantage of Ukraine's OAP (market supply factor that reflects effectiveness of national business participation within international trade on the relevant segment; due to combination of endogenous and exogenous factors);

- wholesale and retail sales of OAP in Ukraine (factor of market demand for organic agricultural products of Ukrainian and foreign origin, identifies volumes of final and intermediate consumption by the population and business of Ukraine (B2B and B2C markets));

- area for OAP production in Ukraine (endogenous factor that creates resource prerequisites for increasing production and export activity of Ukrainian business in a particular sphere on its various directions).

A multifactor regression model has been built for comprehensive investigation by using the software product of E-Views; the hypothesis of the impact on exports of organic food products of exogenous and endogenous factors has been tested as follows: $Y=f\left(F_{e n}, F_{e x}\right)$,

where $F_{e n}$ are internal factors, $F_{e x}$ are external factors.

\section{Research results}

Among the tested internal factors, the most significant, when taking into account the time range, was the indicator of wholesale and retail sales of OAP and the indicator of the area allocated for production of OAP in Ukraine. The most significant external factor, which at the same time is formed on the grounds of internal sources and preconditions, is the index of relative advantage of domestic exports of the OAP. Statistical data for analysis are taken through the period of 2008-2019, and therefore, the model includes 12 observations (Table 1 ).

The general view of the model on factors influencing external variables for export of OAP was described by the equation:

$$
E=C(1){ }^{*} R X A_{i j}+C(2){ }^{*} X 2+C(3) * X 3+C(4),
$$

Table 1

Statistics data of a multifactor regression model

\begin{tabular}{|c|c|c|c|c|}
\hline obs & $\mathrm{E}(\mathrm{Y})$ & $\mathrm{RXA}_{\mathrm{ij}}(\mathrm{X} 1)$ & $\mathrm{WRS}_{\text {oap }}(\mathrm{X} 2)$ & $\mathrm{S}_{\text {oap }}(\mathrm{X} 3)$ \\
\hline 2008 & 14.53 & 1.1022424 & 0.6 & 269984 \\
\hline 2009 & 37.65 & 3.07397965 & 1.2 & 270193 \\
\hline 2010 & 39.73 & 2.704579 & 2.4 & 270226 \\
\hline 2011 & 41.8 & 2.207459 & 5.1 & 272850 \\
\hline 2012 & 44.83 & 1.935292 & 7.9 & 393400 \\
\hline 2013 & 47.76 & 1.947208 & 12.2 & 400764 \\
\hline 2014 & 67.89 & 2.3425489 & 14.5 & 310550 \\
\hline 2015 & 50.15 & 1.84531 & 21.2 & 289000 \\
\hline 2016 & 59.05 & 2.056656274 & 29.43 & 309100 \\
\hline 2017 & 98.62 & 3.693409 & 33 & 497980 \\
\hline 2018 & 103.98 & 3.059986578 & 36 & \\
\hline 2019 & 271.67 & 7.402071 & & \\
\hline
\end{tabular}

Source: calculated by the authors using data from UNCTAD, Research Institute of Organic Agriculture (FiBL), the International Federation of Organic Agriculture Movements (IFOAM) and the Federation of Organic Movement of Ukraine 
where $E$ is the export of Ukraine OAP, mln EUR;

$R X A_{i j}$ is Ukraine's index of relative export advantage of OAP;

$W R S_{\text {oap }}$ are wholesale and retail sales of OAP in Ukraine, mln EUR;

$S_{\text {oap }}$ is the area for production of OAP in Ukraine, hectare.

In the process of model analysis, correlations between the selected variables were identified and a correlation matrix was constructed that explains them (Table 2).

Table 2

Correlation matrix

\begin{tabular}{|c|c|c|c|c|}
\hline & $\mathrm{E}$ & $\mathrm{RXA}_{\mathrm{ij}}$ & $\mathrm{WRS}_{\text {oap }}$ & $\mathrm{S}_{\text {oap }}$ \\
\hline $\mathrm{E}$ & 1 & 0.9522 & 0.7849 & 0.66764 \\
\hline $\mathrm{RXA}_{\mathrm{ij}}$ & 0.9522 & 1 & 0.6495 & 0.5171 \\
\hline $\mathrm{WRS}_{\text {oap }}$ & 0.78495 & 0.6495 & 1 & 0.5880 \\
\hline $\mathrm{S}_{\text {oap }}$ & 0.6676 & 0.5171 & 0.5880 & 1 \\
\hline
\end{tabular}

Source: based on authors' calculations

Basing on the matrix data, a strong positive correlation is inherent between all endogenous and exogenous factors and OAP exports: the relationship between RXAij and $\mathrm{E}$ is being quite tough $95 \%, 78 \%$ between WRSoap and E, and $68 \%$ between Soap and E. The connection among all variables is within acceptable limits, which indicates the absence of multicollinearity. It can be argued that the more competitive domestic organic agricultural food products are, the more exports will grow.

The results of selected factors influencing within 12 periods are represented in Table 3.

The first step is aimed at analyzing the results of multifactor regression of OAP export growth. In this model we use $10 \%$ level of significance. Analysis of Table 3 has led to the following results:
1. All selected factors have positive effect on the export of OAP. With the growth of index of the relative advantage of domestic exports of the OAP by $1 \%$, exports of organic agricultural food products increase up to $30 \%$; growth of wholesale and retail sales of OAP leads to an increase in exports of these products up to $1 \%$. The dimensions of the area allocated for the production of OAP has no special effect, but their effective use leads to increased crops and, accordingly, to an increase in exports.

2 . The value of regression $\mathrm{R} 2$ shows how many selected exogenous and endogenous variables are related to the Ukraine's export of OAP. According to regression calculations, $97 \%$ growth of $\mathrm{E}$ depends on these factors. This indicates strong enough connection, since there are other factors, both quantitative and qualitative that affect $\mathrm{E}$. The probability of accepting the null hypothesis is close to zero Prob. (F-statistic) $=0.00$, which confirms the alternative hypothesis indicating the significance of the equation in the whole. According to Fisher's F-statistics, not all coefficients of the regression equation are equal to zero at the same time. In addition, all the selected factors are significant in terms of the impact on E: the index of relative advantage of domestic OAP exports $-0.00 \%$; wholesale and retail sales of $\mathrm{OAP}-3.5 \%$, and the area for OAP manufacture $-6 \%$, which corresponds to marginal value less than $10 \%$. As a rule, there are no strict requirements for the constants, but in our case it is also statistically significant, because it is less than $1 \%$, i.e., all three indicators are statistically significant.

3. Using the Durbin-Watson criterion, we check the equation on for the availability of high-priority autocorrelation: this criterion (Durbin-Watson stat) is 1.86. We determine significant (critical) points $\mathrm{dL}$ and $\mathrm{dU}$. For the number of observations of

Table 3

The results of multifactor regression of OAP export growth

Dependent Variable: E

Method: Least Squares

Sample: 20082019

Included observations: 12

\begin{tabular}{lclcc}
\hline \hline \multicolumn{1}{c}{ Variable } & Coefficient & Std. Error & t-Statistic & Prob. \\
\hline \multicolumn{1}{c}{ RXA $_{\text {ij }}$} & 30.43697 & 3.367611 & 9.038150 & 0.0000 \\
WRS $_{\text {oap }}$ & 1.161601 & 0.457623 & 2.538338 & 0.0348 \\
\multicolumn{1}{c}{ Soap $_{\text {C }}$} & 0.000144 & $6.60 \mathrm{E}-05$ & 2.180745 & 0.0608 \\
\multicolumn{1}{c}{ R-squared } & -77.38451 & 19.19558 & -4.031371 & 0.0038 \\
Adjusted R-squared & 0.971549 & Mean dependent var & & 73.13833 \\
S.E. of regression & 0.960879 & S.D. dependent var & & 67.42526 \\
Sum squared resid & 13.33601 & Akaike info criterion & & 8.280015 \\
Log likelihood & 1422.794 & Schwarz criterion & & 8.441650 \\
F-statistic & -45.68009 & Hannan-Quinn criter. & & 8.220172 \\
Prob(F-statistic) & 91.06033 & Durbin-Watson stat & & 1.863769 \\
\hline \hline
\end{tabular}

Source: based on authors' calculations 
12 and 3 variables at a significance level of $\alpha=5 \%$, $0.658<\mathrm{DW}<1.864 ; \alpha=1 \%, 0.449<\mathrm{DW}<1.373$. This means that if $\alpha=5 \%$, the indicators are on the edge of the uncertainty zone and the zone when we have no reason to reject the null hypothesis; if $\alpha=1 \%$, we do not unequivocally reject the null hypothesis, and confirm no availability of high-priority autocorrelation.

The second step is to check on for autocorrelation of the second and higher levels using the BreuschGodfrey test (Table 4). The results of this table show that autocorrelation does not exist (in the equation of provided Prob. more than $10 \%$ of the significance level and equals to $32 \%$ ). Also at $5 \%$ of significance level RESID $(-1)=0.3065$ and RESID $(2)=0.5360$, which is more than $5 \%$ that confirms the absence of autocorrelation.

The third step is to check other information criteria. Some other criteria in the table, such as Akaike, Schwarz, Hannan-Quinn, are small, confirming the success of the model.

The fourth step is to test the model for its success, namely for the presence of heteroscedasticity. We check this model for heteroscedasticity using tests: White,
Harvey, Glejser, Breusch-Pagan-Godfrey, and ARCH. The test results are shown in Table 5.

The constructed equation has passed a number of tests for autocorrelation, the availability of heteroscedasticity, which confirmed the correctness of the constructed equation, so the model is adequate. However, polynomials can be also used to improve quality.

The fifth step is to check the model for explanatory ability because the constructed model should quite accurately reflect the growth of Ukrainian exports of OAP using the available independent variables (Table 6). As it can be seen from the table, the simulated Fitted values accurately reflect the valid Actual values, therefore, according to this criterion, the model is completely acceptable.

Descriptive characteristics of the model variables are given in Table 7 . The maximum standard deviation is $\mathrm{E}$ and $\mathrm{S}_{\text {oap }}$ which confirms their general trend towards variability and means that both external and internal factors affect these variables. All skewness coefficients are positive, indicating right-sided asymmetry, and have sharper apical distributions than the normal distribution.

Table 4

Breusch-Godfrey Serial Correlation LM Test

\begin{tabular}{|c|c|c|c|c|}
\hline F-statistic & 0.714686 & Prob. $\mathrm{F}(2,6)$ & & \\
\hline Obs*R-squared & 2.308736 & Prob. Chi-Square(2) & & \\
\hline \multicolumn{5}{|c|}{ Test Equation: Sample: 20082019} \\
\hline \multicolumn{5}{|c|}{ Included observations: 12} \\
\hline \multicolumn{5}{|c|}{ Presample missing value lagged residuals set to zero. } \\
\hline Variable & Coefficient & Std. Error & t-Statistic & Prob. \\
\hline $\mathrm{RXA}_{\mathrm{ij}}$ & -0.202335 & 3.601548 & -0.056180 & 0.9570 \\
\hline $\mathrm{WRS}_{\text {oap }}$ & -0.342246 & 0.574760 & -0.595460 & 0.5733 \\
\hline$S_{\text {oap }}$ & 4.20E-05 & 7.84E-05 & 0.536428 & 0.6110 \\
\hline $\mathrm{C}$ & -9.388575 & 22.03306 & -0.426113 & 0.6849 \\
\hline $\operatorname{RESID}(-1)$ & -0.306460 & 0.454760 & -0.673893 & 0.5255 \\
\hline $\operatorname{RESID}(-2)$ & -0.536071 & 0.462786 & -1.158356 & 0.2907 \\
\hline R-squared & 0.192395 & Mean dependent var & & $1.07 \mathrm{E}-14$ \\
\hline Adjusted R-squared & -0.480610 & S.D. dependent var & & 11.37299 \\
\hline S.E. of regression & 13.83869 & Akaike info criterion & & 8.399666 \\
\hline Sum squared resid & 1149.056 & Schwarz criterion & & 8.642120 \\
\hline Log likelihood & -44.39800 & Hannan-Quinn criter. & & 8.309902 \\
\hline F-statistic & 0.285874 & Durbin-Watson stat & & 1.931916 \\
\hline Prob(F-statistic) & 0.904653 & & & \\
\hline
\end{tabular}

Source: based on authors' calculations

Table 5

The Heteroscedasticity Test

\begin{tabular}{|l|c|c|c|c|}
\hline Heteroscedasticity Test: White & Obs*R-squared & 5.034470 & Prob. Chi-Square(9) & 0.4163 \\
\hline Heteroscedasticity Test: Harvey & Obs*R-squared & 2.040894 & Prob. Chi-Square(3) & 0.2931 \\
\hline Heteroscedasticity Test: Glejser & Obs*R-squared & 3.449446 & Prob. Chi-Square(3) & 0.1962 \\
\hline Heteroscedasticity Test: Breusch-Pagan-Godfrey & Obs*R-squared & 2.200232 & Prob. Chi-Square(3) & 0.2054 \\
\hline Heteroscedasticity Test: ARCH & Obs*R-squared & 1.059496 & Prob. Chi-Square(1) & 0.2675 \\
\hline
\end{tabular}

Source: based on authors' calculations 
Table 6

Explanatory ability of the model

\begin{tabular}{|c|c|c|c|c|}
\hline obs & Actual & Fitted & Residual & Residual Plot \\
\hline 2008 & 14.5300 & -4.27778 & 18.8078 & * * \\
\hline 2009 & 37.6500 & 56.4630 & -18.8130 & 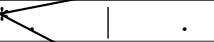 \\
\hline 2010 & 39.7300 & 46.6182 & -6.88821 & . \\
\hline 2011 & 41.8000 & 34.6372 & 7.16276 & . \\
\hline 2012 & 44.8300 & 29.9699 & 14.8601 & * \\
\hline 2013 & 47.7600 & 52.6792 & -4.91919 & K \\
\hline 2014 & 67.8900 & 68.4438 & -0.55381 & . \\
\hline 2015 & 50.1500 & 57.6219 & -7.47194 & . \\
\hline 2016 & 59.0500 & 64.7049 & -5.65495 & . \\
\hline 2017 & 98.6200 & 110.816 & -12.1956 & . \\
\hline 2018 & 103.980 & 98.5762 & 5.40384 & . \\
\hline 2019 & 271.670 & 261.408 & 10.2622 & . \\
\hline
\end{tabular}

Source: based on authors' calculations

Table 7

Characteristics of model variables

\begin{tabular}{|l|c|c|c|c|}
\hline & $\mathrm{E}$ & $\mathrm{RXA}_{\mathrm{ij}}$ & $\mathrm{WRS}_{\text {oap }}$ & $\mathrm{S}_{\text {oap }}$ \\
\hline Mean & 73.13833 & 2.780895 & 15.04417 & 336295.0 \\
\hline Median & 48.95500 & 2.275004 & 13.35000 & 299050.0 \\
\hline Maximum & 271.6700 & 7.402071 & 36.00000 & 497980.0 \\
\hline Minimum & 14.53000 & 1.102242 & 0.600000 & 269984.0 \\
\hline Std. Dev. & 67.42526 & 1.609809 & 12.53617 & 0.751656 \\
\hline Skewness & 2.324105 & 2.096382 & 0.441001 & 2.355304 \\
\hline Kurtosis & 7.542405 & 6.894447 & 1.844507 & 1.337789 \\
\hline & & & & 0.512275 \\
\hline Jarque-Bera & 21.11965 & 16.37299 & 0.589623 & 4035540. \\
\hline Probability & 0.000026 & 0.000278 & & $6.56 \mathrm{E}+10$ \\
\hline & & & 180.5300 & 1728.711 \\
\hline Sum & 877.6600 & 33.37074 & & 12 \\
\hline Sum Sq. Dev. & 50007.82 & 28.50633 & & \\
\hline Observations & 12 & 12 & & \\
\hline
\end{tabular}

Source: based on authors' calculations

Let us analyze the index of kurtosis, which shows the amplitude of deviations of variables. This figure is more than zero, which also indicates an acute apical distribution. In our model all indicators of excess are more than zero, so the distribution is sharply acute.

Let us check the model for predictive quality: we pay attention to the MAPE criterion. For each integrated risk indicator an approach is defined that allows to correct the minimum forecast error. In our case, the criterion MAPE (in Actual $\mathrm{Y}=\mathrm{E}$ ) $=25.33$, which means acceptable (but not high) accuracy of the forecast (Figure 1)

The equation is statistically significant with a high coefficient of determination. The general form of the dependence model of foreign trade upon independent variables can be described by the following equation:

$$
\begin{aligned}
& \mathrm{E}=30.4369 * \mathrm{RXA}_{\mathrm{ij}}+1.1616^{*} \mathrm{WRS}_{\text {oap }}+ \\
& +0.0001{ }^{*} \mathrm{~S}_{\text {oap }}-77.3845
\end{aligned}
$$

The constructed model has been checked for autocorrelation and tested for heteroscedasticity, as well as verification applied for explanatory and predictive quality. The results of the authors' model proved its adequacy and high quality.

This equation shows the dependence of OAP exports (E) upon the Index of relative advantage of domestic OAP exports $\left(\mathrm{RXA}_{\mathrm{ij}}\right)$, wholesale and retail sales of OAP in Ukraine ( $\mathrm{WRS}_{\text {oap }}$ ), and the area of land allocated for the OAP production (Soap). The coefficients of the equation show the influence of each factor on the performance indicator along with the constancy of other indicators. In this case, the export of the OAP increases by 30.4 units with growing Index of the relative advantage of domestic OAP exports by 1 unit while the other two indicators remain unchanged. A $1 \%$ increase in wholesale and retail sales of OAP in Ukraine will enlarge OAP exports up to $1.16 \%$. The area for $\mathrm{OAP}$ manufacturing does not significantly 


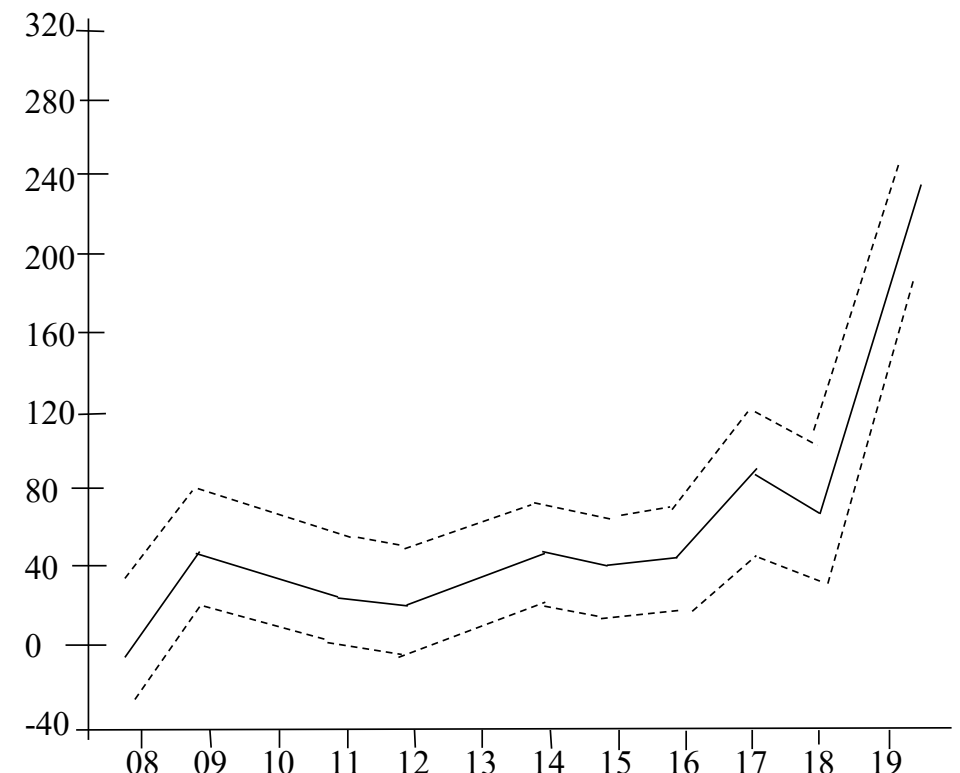

Figure 1. Forecasting

Source: based on authors' calculations

\section{Forecast: YF}

Actual: Y

Forecast sample: 20082019

Included observations: 12

Root Mean Squared Error $\quad 10.88881$

Mean Absolute Error $\quad 9.416106$

Mean Abs. Percent Error $\quad 25.33016$

Theil Inequality Coefficient $\quad 0.055985$

Bias Proportion 0.000000

Variance Proportion $\quad 0.007216$

Covariance Proportion $\quad 0.992784$ affect the OAP export; this indicates that the extensive way of expanding the area for organic agricultural production is not crucial for increasing exports. Using the latest technologies for intensification of agricultural production, it is possible to achieve significant increase in the volume of OAP, and accordingly its exports.

The results of the obtained econometric model allow to determine the necessary focus of state policy, taking into account the variability of factors importance to increase the OAP export.

\section{Implications}

The conducted research and retrospective review of the literature indicates the importance of the chosen problem both for the agrarian business of Ukraine and world trade in general. Claiming to strengthen the role of the OAP exporter, Ukraine will have to carry out number of structural reforms, starting with the opening of the agricultural land market, which is currently closed to non-residents, and the institutional compatibility of national standards of quality and safety of organic food to international requirements.

An important task for Ukrainian exporters of organic agro-food products to solve in the nearest future is to ensure information transparency on conditions of creating, processing, transportation and, in fact, trade in it. After all, importers-consumers of organic food products are increasingly concerned about food security and food safety. Moreover, the demand for the ability to provide such informational openness for the producers/exporters themselves is almost the only condition for access to this special segment of the world market, which is organic agricultural products.
The issue of information support is not only Ukrainian concern but also has an institutional dimension on global and national levels. The collection of structured information throughout the supply chain, including the level of primary production, processing, distribution, and the level of trade-related international processes, imports and retail trade, should be considered within the framework of agro-food trade just to achieve inclusive and sustainable development of the global economy.

In the case of organic agro-food products, against the background of the intensification of neoprotectionist slogans as for the safety of national business and restriction of imports in the context of the COVID-19 pandemic, a balance needs to be struck between reasonable security concerns and trade facilitation. In this sense, the solution, in our opinion, is maybe more active application of an integrated approach to information management throughout the value chain, rather than just monitoring transactions among the participants in foreign economic activity, which is already actively implemented in mutual "digital" trade between 32 Asian countries of the Pacific (ESCAP 2021). Global unique identification is one of the key principles needed to manage agro-food chain information. Although any food traded globally requires unique identification, being crucially significant for organic products, where they allow the entire evolution of measures and processes to be traced in order to avoid any risk/jeopardy (for example, ones associated in particular with cross-contamination).

Another problem is that currently there is no predominant identification provider for the agricultural component of agro-food chains, or in general for the 
early stages of the food supply chain. So far, at certain stages, in particular at the stage of distribution and retail trade, the leading provider of identification schemes is GS1. On early stages, non-global identification systems are mainly used. All this complicates the removal of information uncertainty jeopardy and bears destructive effect onto the entire international trade of organic agrofood products.

Digitization of Ukrainian exports of organic agricultural products should be a logical step in its further expansion in order to ensure information transparency on conditions of creation, processing, transportation and international trade. Preliminary assessments of the digital transformation of Ukraine's economy effect upon the macro level have already been conducted, and conclusions have been drawn on its impact in accelerating economic growth and increasing global competitiveness (Tkalenko et al., 2021).

\section{Conclusions}

As a result of modeling, the following issues have been found:

- Ukraine's achievement and increase of relative advantage within international trade in organic agrofood products for the outlined period of time;

- the existence of strong connections between the volume of exports of organic agro-food products and the level of comparative advantages of the country in international trade;

- identification of significant impact upon exports of endogenous factors, namely the level of wholesale and retail sales on domestic market of Ukraine as a factor that creates additional demand from the population and business of Ukraine (B2B and B2C markets) for organic products, and enhances the attention of agricultural manufacturers onto species activities that combine the criteria of high profitability and public demand;

- another endogenous factor is the amount of land allocated for organic farming, that has shown insignificant impact, however, it allows to create resource conditions for increasing production and export activity of national business within a particular sphere in its various directions, from meat and dairy products to production of organic fruit, vegetables, etc.

Prospects for further research in this area may assess the potential of international production and marketing cooperation between Ukrainian rural companies and non-resident companies in terms of limiting the latter's access to the land market in Ukraine and finding flexible mechanisms for stimulation of joint manufacture and sale of organic agricultural products on international markets, in accordance with quality and safety standards.

\section{Acknowledgements}

The article is prepared within the framework of the Scientific research work "The potential of import substitution in Ukraine on conditions of postindustrial economy formation" (state registration number 0119U100625) and "The strategy of structural reorientation of the Ukrainian economy in conditions of pandemic" (state registration number 0121U109608).

\section{References:}

Aitken, R., Watkins, L., Williams, J. and Kean A. (2020). The Positive Role of Labelling on Consumers ` Perceived Behavioral Control and Intentional to Purchase Organic Food. Journal of Cleaner Production, Volume 255, 10 May 2020. Retrieved 04 March, 2021 from: https://doi.org/10.1016/j.jclepro.2020.120334

Baquedano, Felix, Cheryl Christensen, Kayode Ajewole, and Jayson Beckman (2020). International Food Security Assessment, 2020-30, GFA-31, U.S. Department of Agriculture, Economic Research Service, August 2020. Retrieved 02 March, 2021 from: https://www.ers.usda.gov/webdocs/outlooks/99088/gfa-31.pdf?v=7271.5/

Bazaluk, O., Yatsenko, O., Zakharchuk, O., Ovcharenko, A., Khrystenko, O. and Nitsenko, V. (2020). Dynamic Development of the Global Organic Food Market and Opportunities for Ukraine. Sustainability 12, no. $17: 6963$. Retrieved 12 March, 2021 from: https://doi.org/10.3390/su12176963

Dudar, V. (2019). Competitive advantages of organic agro-food products properties from the standpoint of marketing. Bulletin of Ternopil National University of Economics, no. 1, pp. 131-140. URL file:///C:/Users/ Professional/Downloads/Vtneu_2019_1_12.pdf

ESCAP, The Economic and Social Commission for Asia and the Pacific. (2021). Trade facilitation in times of crisis and pandemic: Practices and lessons from the Asia-Pacific region. Retrieved $26 \mathrm{March}, 2021$, P. 36. Retrieved 12 April, 2021 from: https://www.unescap.org/sites/default/d8files/knowledge-products/Regional\%20report-Trade\%20 facilitation\%20in\%20times\%20of\%20crisis\%20and\%20pandemic_0.pdf.

Ganush, G. I. (2013). Prospects for the development of production of environmentally safe (organic) food products in Belarus. Sustainable development of agriculture in Belarus within new conditions. Inst. research. in the APC of Nat. acad. Science of Belarus. Minsk, pp. 41-44.

Greene, C., Carolyn, D., Biing-Hwan, L., William, McB., Oberholtzer, L. and Travis, S. (2009). Emerging Issues in the U.S. Organic Industry. EIB-55. Economic Research Service, U.S. Dept. of Agriculture, Number 55 June 2009 , P. 36. Retrieved 18 March, 2021 from: https://www.ers.usda.gov/webdocs/publications/44406/9397_eib55_1_. $\mathrm{pdf} ? \mathrm{v}=0$ 
Jaouen, A., Jaeck, M., Joly C. and Kessari, M. (2020). Les magasins de producteurs: vers un renouveau de l'action collective des PME agricoles. Revue internationale P.M.E., Volume 33, Numero 3-4, pp. 261-296. Retrieved 06 March, 2021 from: https://doi.org/10.7202/1074816ar.

Makhnovets, M. (2020). How to find your place in global organic trade? APK-Inform: 2020, №12 (66). Retrieved 18 March, 2021 from: https://www.apk-inform.com/uk/exclusive/topic/1506789.

Muñoz-Sanchez, V. \& Flores, A. M. (2021). The Connections between Ecological Values and Organic Food: Bibliometric Analysis and Systematic Review at the Start of the 21st Century. Sustainability, 13 (7), 3616. Retrieved 02 April, 2021 from: https://doi.org/10.3390/su13073616.

Mykhaylenko, O. G. (2017). Analysis of international trade in organic agricultural products development. Bulletin of the Odessa National University. Series: Economics, Vol. 22(5), pp. 33-38. Retrieved 06 February, 2021 from: http://nbuv.gov.ua/UJRN/Vonu_econ_2017_22_5_8.

Nagachevska, T., Apostol, M., Fedun, I., Kuzioma, O., \& Prygara, O. (2021). Mechanisms for Attracting Foreign Investment in the Agrarian Sector of Ukraine. The Importance of New Technologies and Entrepreneurship in Business Development: In The Context of Economic Diversity in Developing Countries: The Impact of New Technologies and Entrepreneurship on Business Development, ICBT 2020, vol. 194, 960-976. DOI: https://doi.org/10.1007/978-3-030-69221-6_74.

Oberholtzer, L., Carolyn, D. and Jaenicke, C.E. (2013). International trade of organic food: Evidence of US imports. Renewable Agriculture and Food Systems. Volume 28, Issue 3, pp. 255-262. Retrieved 12 December, 2020 from: https://doi.org/10.1017/S1742170512000191

Schäufele, I. and Hamm, U. (2017). Consumers' perceptions, preferences and willingness-to-pay for wine with sustainability characteristics: A review. Journal of Cleaner Production, Vol. 147, 20 March 2017, pp. 379-394. Retrieved 10 March, 2021 from: https://doi.org/10.1016/j.jclepro.2017.01.118.

Tkalenko, S., Sukurova, N., Kudyrko, L., and Litvin, N. (2021) Digitization of Investment-Innovation Development of Ukrainian Economy: Empirical Analysis. In: Antipova T. (eds) Comprehensible Science. ICCS 2020. Lecture Notes in Networks and Systems, vol 186, pp. 43-60. Retrieved 24 March, 2021 from: https://doi.org/10.1007/978-3030-66093-2_5

Tsvitko, E. (2018). State and trends of the world market of organic products. Bulletin of BarSU. Series: Economic Sciences. Minsk, vol. 6/2018, pp. 103-108.

Varia, F., Macaluso, D., Agosta, I., Spatafora, F. and Giovanni D.G. (2021). Transitioning towards Organic Farming: Perspectives for the Future of the Italian Organic Wine Sector. Sustainability, 13, no. 5: 2815. Retrieved 04 April, 2021 from: https://doi.org/10.3390/su13052815

Willer, H., Schlatter, B., Trávníček, J., Kemper, L. and Lernoud, J. (Eds.) (2020). The World of Organic Agriculture Statistics and Emerging Trends 2020. 21st edition. Research Institute of Organic Agriculture (FiBL) and IFOAM - Organics International, Frick and Bonnhttps. Retrieved 15 March, 2021 from: https://orgprints.org/ id/eprint/37222/ 